\title{
Heat transfer and rheology of stirred yoghurt during cooling in plate heat exchangers
}

\author{
Isabel M. Afonso ${ }^{\mathrm{a}, \mathrm{b}}$, Lubos Hes ${ }^{\mathrm{c}}$, João M. Maia ${ }^{\mathrm{d}}$, Luis F. Melo ${ }^{\mathrm{a}, *}$ \\ ${ }^{a}$ LEPAE, Departamento de Engenharia Química, Faculdade de Engenharia, Universidade do Porto, 4200-465 Porto, Portugal \\ ${ }^{\mathrm{b}}$ Escola Superior Agrária de Ponte de Lima, Instituto Politécnico de Viana do Castelo, Refóios, 4990-706 Ponte de Lima, Portugal \\ ${ }^{\mathrm{c}}$ Technical University of Liberec, Faculty of Textiles, Halkova 6, 46117 Liberec, Czech Republic \\ d Departamento de Engenharia de Polimeros, Universidade do Minho, 4800-058 Guimarães, Portugal \\ Received 25 February 2000; received in revised form 19 November 2001; accepted 24 June 2002
}

\begin{abstract}
In the present work an experimental investigation was conducted to obtain a correlation for the determination of convective heat transfer coefficients of stirred yoghurt in a plate heat exchanger. A rheological study was carried out in order to characterise the stirred yoghurt flow behaviour, evaluating its dependency both on shear rate and temperature. A shift in the temperature dependency was evidenced at $25^{\circ} \mathrm{C}$. It is also shown that the material shows a complex flow behaviour, changing from a Bingham fluid to a power-law fluid at shear stresses in excess of approximately 6.7 Pa. As regards the heat transfer behaviour of the non-Newtonian stirred yoghurt a correlation for the convective heat transfer coefficient was obtained that reveals the large effects of the thermal entry length due to the high Prandtl numbers and to the short length of the plate heat exchanger.
\end{abstract}

(C) 2002 Elsevier Science Ltd. All rights reserved.

\section{Introduction}

Thermal processing of food products, ranging from mild to relatively severe treatments, is a common operation in the food industry, where physical modifications affecting the structure and stability of the final product are achieved, mainly to preserve its quality and prevent spoilage (Corrieu, Noël, \& Maingonnat, 1985; Rao, 1986). The knowledge of engineering properties, such as density, specific heat and thermal conductivity, as well as of the flow characteristics and the heat transfer behaviour of food processing fluids is very important for the proper design of industrial plants, definition of levels of product quality and control of manufacturing processes.

Fluid foodstuffs can exhibit Newtonian or nonNewtonian behaviour, depending on their physical properties (composition and structural complexity) and industrial processing conditions. Although many of the food fluids are non-Newtonian, they are often treated as Newtonian in process calculations; the more viscous the

\footnotetext{
${ }^{*}$ Corresponding author. Fax: +351-22-5081449.

E-mail address: 1melo@fe.up.pt (L.F. Melo).
}

product is, the more essential it is to use non-Newtonian analysis (Hallström, Skjöldebrand, \& Trägårdh, 1988).

Stirred yoghurt is a typical non-Newtonian fluid, which is the result of milk acidification by fermentation with lactic acid bacteria, e.g., Lactobacillus delbrueckii subsp. bulgaricus and Streptococcus salivarius subsp. thermophilus (Tamime \& Robinson, 1988). In stirred yoghurt production, milk is inoculated and incubated in a fermentation tank at a suitable temperature, normally $40-43{ }^{\circ} \mathrm{C}$, for approximately $21 / 2-4 \mathrm{~h}$, and the formed yoghurt gel is subsequently broken during the stirring, cooling and packaging stages.

The influence of factors such as total solids content, type of starter culture, heat treatment and cooling conditions on the rheological properties of stirred yoghurt has been studied by several authors using different rheological methods (Afonso \& Maia, 1999; Arshad, Paulsson, \& Dejmek, 1993; Benezech \& Maingonnat, 1993, 1994; Bouzar, Cerning, \& Desmazeaud, 1997; Kaláb, Wojtas, \& Told, 1983; Lucey, Teo, Munro, \& Singh, 1997; Parnell-Clunies, Kakuda, deMan, \& Cazzola, 1988). In various reports, its pseudoplastic flow behaviour, partial thixotropic and viscoelastic characteristics were identified (Afonso \& Maia, 1999; Benezech \& Maingonnat, 1993, 1994; Rohm \& Kovac, 1994, 1995; Rönnegård \& Dejmek, 1993). However, the diversity of 


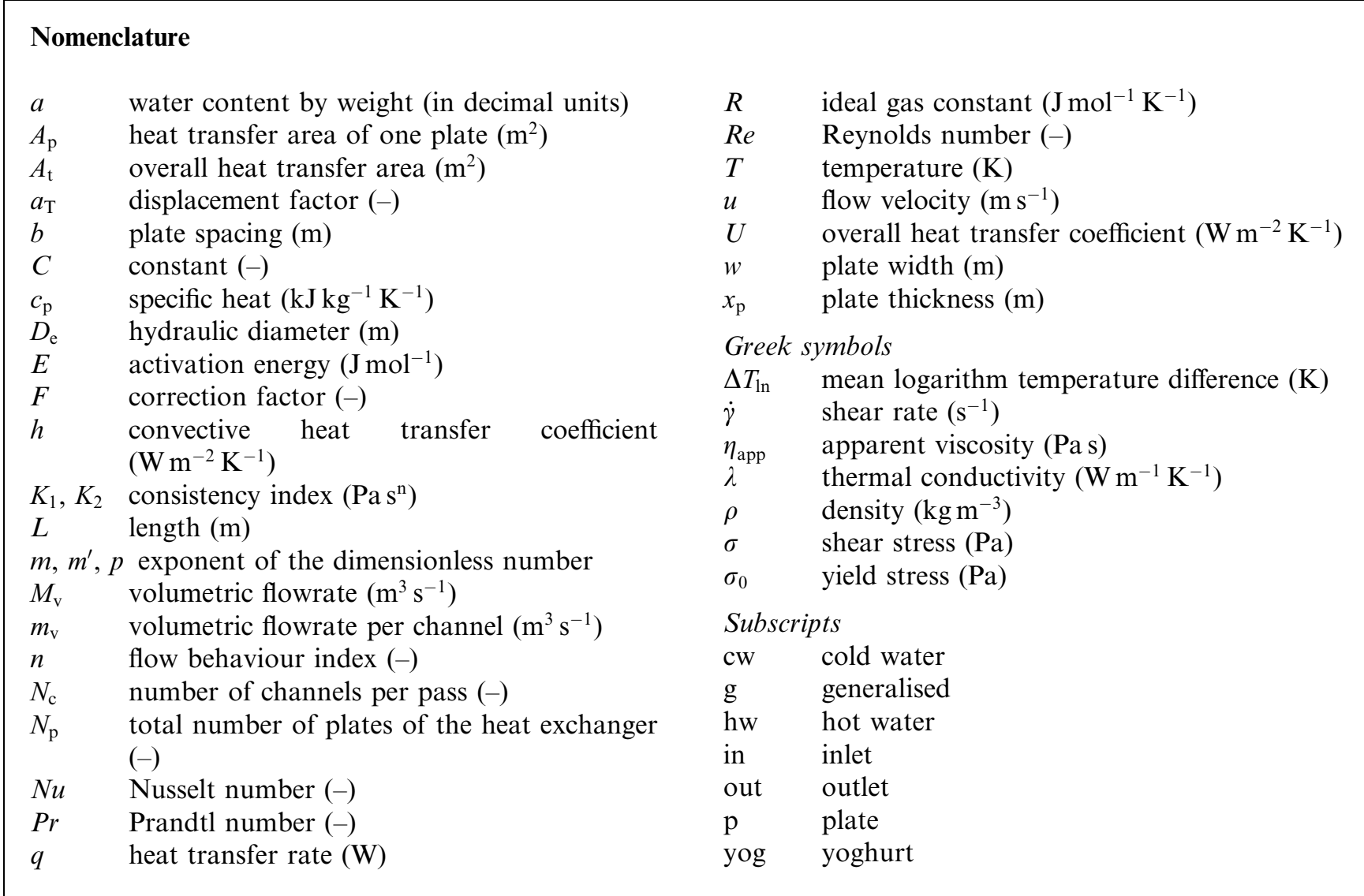

experimental conditions and methodologies, often not specified, makes it difficult to apply those results to a different particular situation under study.

Plate heat exchangers are most suitable for liquidliquid heat transfer duties that require uniform and rapid heating or cooling, as is often the case when treating thermally sensitive fluids such as food fluids. The industrial development of plate heat exchangers was considerable in recent years, particularly in the food industry for viscous food fluids, but the information available for the design of plate heat exchangers using real food fluids, such as stirred yoghurt, is somewhat scanty.

Some studies were published focusing on heat transfer in plate heat exchangers using non-food fluids with viscous Newtonian and non-Newtonian, mainly pseudoplastic characteristics (Bassiouny \& Martin, 1984a,b; Delplace, 1995; Kho \& Müller-Steinhagen, 1999; Leuliet, Maingonnat, \& Lalande, 1987, 1990; Muley, Manglik, \& Metwally, 1999; Rene, Leuliet, \& Lalande, 1991; Rene \& Lalande, 1987). For such fluids, the performances of plate heat exchangers both from a thermal and hydraulic viewpoint, have been determined as a function of hydraulic diameter (Leuliet et al., 1990); pressure drop (Leuliet et al., 1987); flow distribution and arrangement type (Bassiouny \& Martin, 1984a,b; Heggs,
Sandham, Hallam, \& Walton, 1997; Kho \& MüllerSteinhagen, 1999) and plate type (Rene et al., 1991).

The purpose of the present work is to complement some of the information described above by gathering reliable information to predict heat transfer rates of stirred yoghurt during the cooling process in plate heat exchangers. In order to do so, an experimental investigation was conducted in order to obtain a correlation for the determination of convective heat transfer coefficients of stirred yoghurt in a plate heat exchanger.

\section{Experimental description}

\subsection{Rheological characterisation}

The methods used to assess the temperature effect on the rheological properties of yoghurt are essentially similar to those reported previously by Afonso and Maia (1999). Here the experimental procedure is only briefly summarized. The experiments were performed in a VISCOMETERS model ELV-8 with a TCU-3 module, using coaxial cylinders with spindle TL7.

Samples of stirred yoghurt were collected in the experimental set-up, downstream of the plate heat exchanger used in the cooling stage. The temperature 
effect on the rheological properties of yoghurt was studied by means of apparent viscosity measurements at different spindle speeds, ranging from 0.3 to 60 r.p.m, at $5,15,20,25,30,35,40$ and $45^{\circ} \mathrm{C}$. Each experiment was repeated three times, at constant temperature.

\subsection{Heat transfer experiments}

The experimental set-up used for determining the heat transfer coefficient of stirred yoghurt during the cooling stage in a plate heat exchanger is illustrated in Fig. 1. It consists, basically, of a 1001 stainless steel AISI 316 fermentation jacketed tank, a water refrigerating unit, a Pacetti RS 22 series plate heat exchanger, with a maximum of fifteen stainless steel herringbone plates and a Chessel model 4001 (Chessel Ltd., Eurotherm International Group) multichannel microprocessor device. The main geometrical characteristics of the heat exchanger plates are given in Table 1.

Five probes of iron-constantan thermocouples connected to the multichannel microprocessor device were positioned $1.0 \mathrm{~cm}$ away from the inlet and outlet channels of the plate heat exchanger.

Prior to the experiments for the determination of the heat transfer coefficient of stirred yoghurt, the experimental set-up was operated with cold water and hot water in order to determine cooling water heat transfer coefficients at different volumetric flowrates and with different numbers of plates. Any variation in these two operating parameters will be reflected in the fluid ve-
Table 1

Main geometrical characteristics of the herringbone plates used

\begin{tabular}{ll}
\hline Material & Stainless steel AISI 316 \\
\hline Plate model & RS 22 \\
Length $L(\mathrm{~m})$ & 0.265 \\
Width $w(\mathrm{~m})$ & 0.102 \\
Thickness $x_{\mathrm{p}} \times 10^{-3}(\mathrm{~m})$ & 0.5 \\
Distance between plates $b \times 10^{-3}(\mathrm{~m})$ & 2.60 \\
Thermal conductivity $\lambda_{\mathrm{p}}\left(\mathrm{W} \mathrm{m}^{-1} \mathrm{~K}^{-1}\right)$ & 16.3 \\
\hline
\end{tabular}

locity and shear rate, influencing the flow pattern. The experiments were carried out with different numbers of plates $(15,13,11,7$ and 5 plates), keeping the distance between plates constant. The Reynolds numbers varied from 23 to 1270 .

Cold water coming from the refrigerator was pumped by a centrifuge pump (B3), the flowrates being adjusted by means of a globe valve (V3). The temperature of the hot water in the fermentation jacketed tank (T1) was stabilized by means of hot oil circulating in the jacket at a temperature of $45-50{ }^{\circ} \mathrm{C}$.

The flowrates were determined by measuring the volume of fluid exiting the heat exchanger during a given time interval. Flow measurement devices (rotameters, etc.) were avoided in order to minimize the head losses along the flow circuit, that would require more powerful pumping systems with probable undesirable fluid heating. The volumetric flowrate was found to be constant during the experiment.

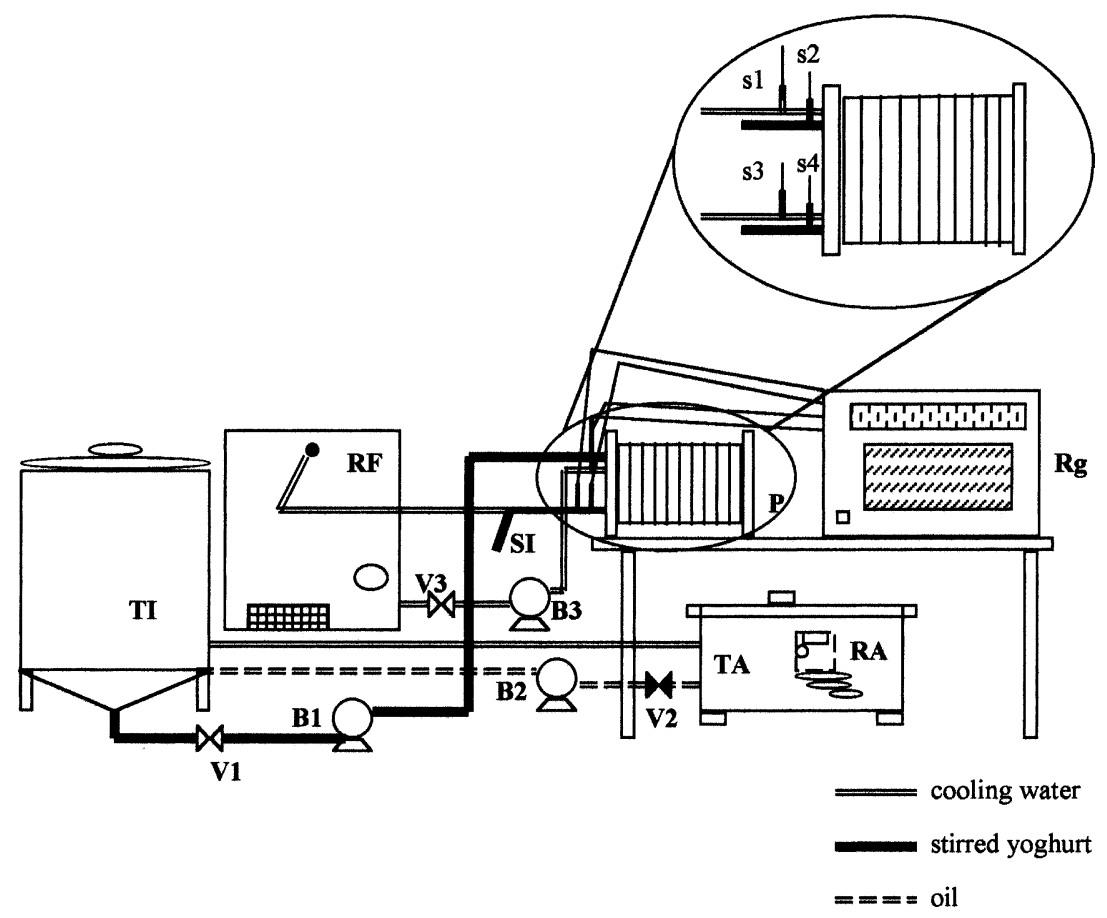

Fig. 1. Experimental set-up (B1: positive pump; B2, B3: centrifuge pumps; P: plate heat exchanger; RA: electric resistance; RF: water refrigerating unit; Rg: multichannel microprocessor device; T1: fermentation tank; TA: hot oil tank; V1, V2, V3: globe valves). 
The experiments for the determination of heat transfer coefficients of the stirred yoghurt included two successive main stages: the stirred yoghurt production and the heat transfer experiments. The tests in the plate heat exchanger with stirred yoghurt were carried out according to the procedure described above for the evaluation of the heat transfer coefficients of the water. The "generalised" Reynolds number (which take into account the rheological behaviour) of the yoghurt varied from 0.51 to 14.47 (corresponding to shear stresses between 24 and $59 \mathrm{~Pa}$ ).

The plate heat exchanger and the inlet/outlet piping were insulated to reduce heat losses. Further heat transfer experiments were carried out in order to determine the pressure drop along the plate heat exchanger.

\subsection{Stirred yoghurt production}

Yoghurt was made from reconstituted low-heat nonfat dry milk supplied by a local dairy plant. This milk contained $55.7 \%(\mathrm{w} / \mathrm{w})$ lactose, $34.0 \%(\mathrm{w} / \mathrm{w})$ protein and $1.5 \%(\mathrm{w} / \mathrm{w})$ fat (values were supplied by the producer).

In each experiment, 501 of reconstituted milk with total solids content adjusted to $12 \%$ and $7 \%(\mathrm{w} / \mathrm{w})$ sugar were prepared. The milk was heated to $95{ }^{\circ} \mathrm{C}$ for $5 \mathrm{~min}$ in an autoclave, cooled to $45^{\circ} \mathrm{C}$ and transfered to the fermentation jacketed tank, where it was innoculated with a local dairy yoghurt starter culture $(3 \%(\mathrm{v} / \mathrm{v}))$, and incubated at $43-45{ }^{\circ} \mathrm{C}$ until the yoghurt coagulum was formed and the desired $\mathrm{pH}$ value $(\mathrm{pH}$ 4.4-4.6) was reached. This was achieved within 3-3 h $30 \mathrm{~min}$. Then, the yoghurt coagulum was broken manually by means of a perforated stirrer, by stirring the coagulum twenty five times times in slow helicoidal movements. This was done in order to insure that the yoghurt coagulum was completely broken and that whey incorporation was promoted. After this operation, the stirred yoghurt was circulated through the plate heat exchanger where it was cooled down by the cold water stream.

\subsection{Determination of thermal conductivity}

Thermal conductivity of the stirred yoghurt was determined using a thermal device ALAMBETA VŠST ÚZCHV (SENSORA Instruments \& Consulting, Liberec, Czech Republic, Hes, Araújo, \& Djulay, 1996). ALAMBETA enables the measurement of the following thermal parameters: thermal conductivity, thermal absortivity, thermal resistance, sample thickness.

Thermal measurements were carried out with yoghurt samples previously prepared as outlined below, repeating each experiment three times for each yoghurt sample.

Sample preparation obeyed a strict procedure. Firstly, square polypropylene bags with average di- mensions $(6.5 \times 6.5) \mathrm{cm}$ and $0.03 \mathrm{~mm}$ of thickness were prepared. Each bag was filled with $25.0 \mathrm{ml}$ of yoghurt sample thermally stabilized at a controlled room temperature of $20^{\circ} \mathrm{C}$, removing the air bubbles. Finally, the bags were sealed in an appropriate thermal apparatus. For each yoghurt sample five bags were prepared.

The sample bag was put on the bottom plate of the ALAMBETA and the analysis was started up when the measuring system of the apparatus (the upper plate) contacted with the bag. After an average time interval of $2 \mathrm{~min}$, the measuring cycle was concluded, and the thermal parameter (thermal conductivity) was registered. The operating conditions were optimized according to the description in the equipment manual.

\section{Heat transfer analysis}

The determination of the convective heat transfer coefficient of stirred yoghurt in the plate heat exchanger was based on the following assumptions: average constant thermal properties (thermal conductivity and specific heat) and convective heat transfer coefficients along the heat exchanger, negligible internal heat generation and negligible free convection.

In the present study the plate heat exchanger was operating with a parallel arrangement and in countercurrent. Thus, the volumetric flowrate of each fluid can be expressed in terms of the number of channels per pass, as follows:

$m_{\mathrm{v}}=\frac{M_{\mathrm{v}}}{N_{\mathrm{c}}}$

where $N_{\mathrm{c}}$ is the number of channels per pass, for each fluid, defined as

$N_{\mathrm{c}}=\frac{N_{\mathrm{p}}-1}{2}$

where $N_{\mathrm{p}}$ is total number of plates of the heat exchanger. The number of channels per pass is equal for the two fluids.

The heat transfer design equation is

$q=A_{\mathrm{t}} F U \Delta T_{\mathrm{ln}}$

where $A_{\mathrm{t}}$ is the heat transfer area of the exchanger and $U$ is the overall heat transfer coefficient.

It is assumed that no significant heat exchange takes place between the equipment and the surrounding air.

The factor $F$, used to correct the mean logarithm temperature difference, was determined graphically (Raju \& Bansal, 1986)

$F=0.942$

If the overall heat transfer coefficient $(U)$ is expressed in terms of the convective and conductive parameters, then Eq. (3) can be rewritten as 
$q=A_{\mathrm{t}} F\left(\frac{1}{\frac{1}{h_{\mathrm{cw}}}+\frac{x_{\mathrm{p}}}{\lambda_{\mathrm{p}}}+\frac{1}{h_{\mathrm{yog}}}}\right) \Delta T_{\mathrm{ln}}$

The total heat transfer area, $A_{\mathrm{t}}$, is calculated by the following equation:

$A_{\mathrm{t}}=A_{\mathrm{p}}\left(N_{\mathrm{p}}-2\right)$

where $A_{\mathrm{p}}$ is the heat transfer area of one plate $\left(0.015 \mathrm{~m}^{2}\right.$, value supplied by the producer), and $\left(N_{\mathrm{p}}-2\right)$ is the number of plates really involved in the heat transfer process.

From the experimental data (inlet and outlet temperatures of cold and hot fluids, volumetric flowrates of the two fluids, total number of plates used, thermophysical properties: specific heat, thermal conductivity and density) of each fluid, it is possible to determine the heat transfer rate in the plate heat exchanger $(q)$. The convective heat transfer coefficients are then calculated from Eq. (4).

The hydraulic diameter in the heat exchanger channels $\left(D_{\mathrm{e}}\right)$ is defined for the plate heat exchanger in terms of plate spacing, $b$ (Çengel, 1998)

$D_{\mathrm{e}}=2 b$

In the determination of the convective heat transfer coefficient of the cold water, using hot water as the heat source, the film heat transfer coefficients of the two fluids were related as follows:

$h_{\mathrm{hw}}=h_{\mathrm{cw}}\left(\frac{R e_{\mathrm{hw}}}{R e_{\mathrm{cw}}}\right)^{p} \frac{\operatorname{Pr}_{\mathrm{hw}}^{m}}{P r_{\mathrm{cw}}^{m^{\prime}}}$

where $h_{\mathrm{hw}}$ is the convective heat transfer coefficient of the hot water, and $m$ and $m^{\prime}$ are the Prandtl number exponents that equal 0.4 or 0.3 , for hot and cold water, respectively (Çengel, 1998).

From Eq. (7) it is possible to obtain a correction factor, $\left(R e_{\mathrm{hw}} / \operatorname{Re}_{\mathrm{cw}}\right)^{p}\left(\operatorname{Pr}_{\mathrm{hw}}^{m} / \operatorname{Pr}_{\mathrm{cw}}^{m^{\prime}}\right)$, necessary to introduce the effects of the viscosity and flowrate differences on heat transfer, particularly on the convective heat transfer coefficients.

In the case of the convective heat transfer coeffcient of stirred yoghurt, "generalised" dimensionless numbers should be used so that the non-Newtonian behaviour of stirred yoghurt is taken into account

$N u=C R e_{\mathrm{g}}^{p} \operatorname{Pr}_{\mathrm{g}}^{m}$

where the "generalised" Reynolds and Prandtl numbers are given by

$R e_{\mathrm{g}}=\frac{u \rho D_{\mathrm{e}}}{\eta_{\mathrm{app}}}$

$\operatorname{Pr}_{\mathrm{g}}=\frac{c_{\mathrm{p}} \eta_{\mathrm{app}}}{\lambda}$

The generalisation of these dimensionless numbers is obtained by introducing the viscosity dependency on the shear rate and temperature, correlated by the following general equation (Barnes, Hutton, \& Walters, 1989):

$\eta_{\text {app }}=\left[\eta_{\text {app }}(\dot{\gamma})\right] \mathrm{e}^{(E / R T)}$

where $\eta_{\text {app }}$ is the apparent viscosity of stirred yoghurt, $\eta_{\text {app }}(\dot{\gamma})$ is the term that takes into account the dependency of viscosity on shear rate, $E\left(\mathrm{~J} \mathrm{~mol}^{-1}\right)$ is the activation energy, $R$ is the constant of ideal gas ( $R=8.31451 \mathrm{~J} \mathrm{~K}^{-1} \mathrm{~mol}^{-1}$ ) and $T$ the absolute temperature $(\mathrm{K})$. The rheological model is obtained by fitting the above equation to the experimental data, at a reference temperature.

The specific heat of stirred yoghurt is assumed constant and is estimated by using the following Siebel correlation (Sweat, 1986):

$c_{\mathrm{p}}=3.35 a+0.84$

where $c_{\mathrm{p}}\left(\mathrm{kJ} \mathrm{kg}^{-1} \mathrm{~K}^{-1}\right)$ is the specific heat of a food at a temperature higher than its freezing temperature, $a$ is the water content of the food, and the constant term 0.84 represents the specific heat of the total solids content (dry matter) of the food material.

\section{Results and discussion}

\subsection{Rheological features of the stirred yoghurt}

Fig. 2 shows the flow curves of the stirred yoghurt, at different temperatures. The yoghurt samples used in the rheological characterisation were collected from the plate heat exchanger operating under hydrodynamic shear stress conditions similar to the industrial ones (flowrate: $50 \mathrm{ml} \mathrm{s}^{-1}$; number of plates: 5). From Fig. 2, it is possible to observe that the apparent viscosity decreased with increasing temperature, the effect being more pronounced for temperatures above $30{ }^{\circ} \mathrm{C}$. The study of the temperature influence on the flow behaviour of stirred yoghurt was based on the method previously reported (see details in Afonso \& Maia, 1999), which follows the method proposed by Mendelson (Nielsen, 1977) to predict the flow behaviour, at different temperatures, by means of the superimposition of the flow curves into a reference curve (the "master curve"). The master curve was determined at a reference temperature of $20{ }^{\circ} \mathrm{C}$, and the temperature effect was evaluated by means of the Arrhenius temperature model. The displacement factor is mathematically defined as $a_{\mathrm{T}}=\dot{\gamma}($ reference $) / \dot{\gamma}(T)$ where $\dot{\gamma}$ (reference) is the shear rate at the reference temperature at a defined shear stress and $\dot{\gamma}(T)$ is the shear rate at a determined temperature $T$, at the same shear stress. The displacement factor dependency on temperature can be observed in Fig. 3, which shows the existence of two distinct regions, corresponding to different temperature dependencies. A shift in the temperature dependency is evidenced at 


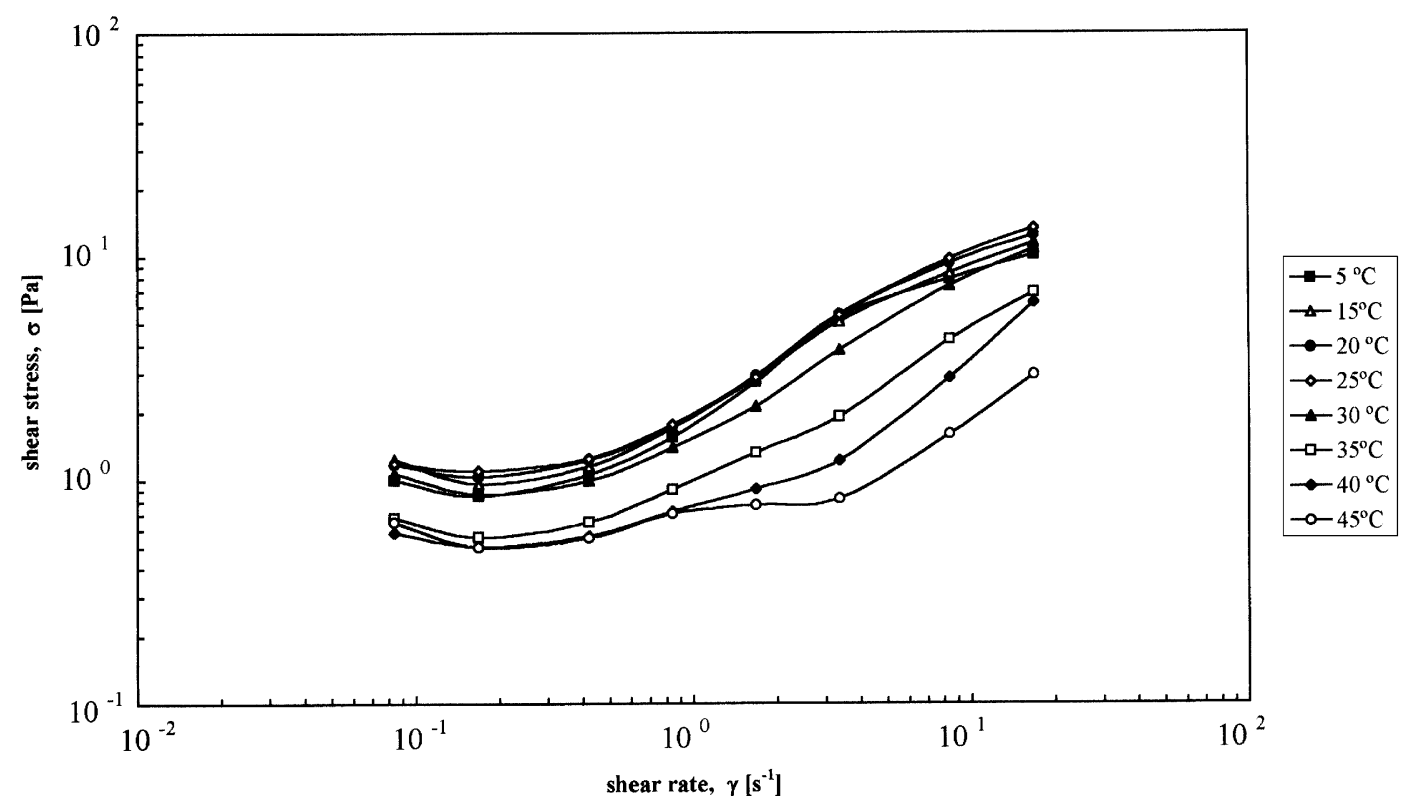

Fig. 2. Flow curves of the stirred yoghurt sample, as a function of temperature.

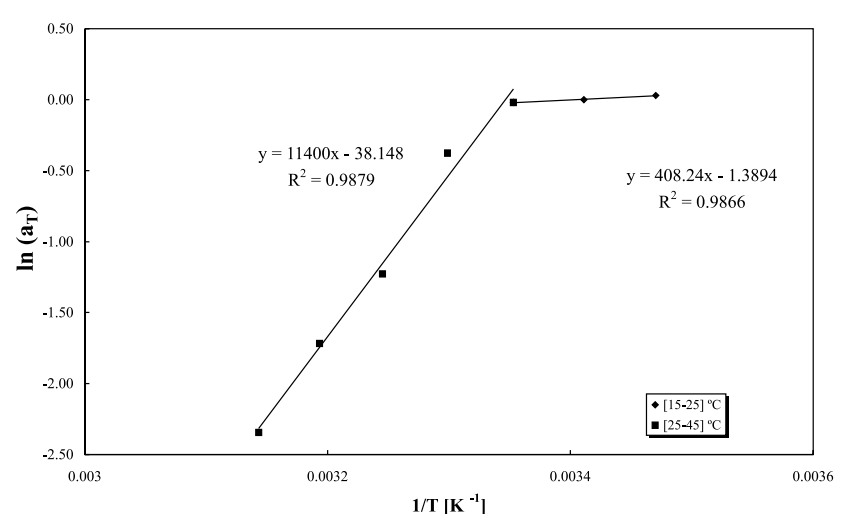

Fig. 3. Displacement factor dependency on temperature of the stirred yoghurt sample.

approximately $25^{\circ} \mathrm{C}$, as indicated by the different slope values; they are related to the activation energy that measures the material's sensitivity to temperature changes. For temperatures below $25{ }^{\circ} \mathrm{C}$, the activation energy is $3394.3 \mathrm{~J} \mathrm{~mol}^{-1}$, and for temperatures above $25^{\circ} \mathrm{C}$ is $94785 \mathrm{~J} \mathrm{~mol}^{-1}$.

Fig. 4 shows the master curve of apparent viscosity versus shear stress at a reference temperature of $20^{\circ} \mathrm{C}$, of a stirred yoghurt sample collected at the outlet stream of the plate heat exchanger. In Fig. 4 it is possible to observe the flow behaviour of the stirred yoghurt and two features are apparent: (i) this fluid has a yield stress (as would be expected); (ii) a change occurs in the slope of the apparent viscosity at a shear stress of approximately $6.7 \mathrm{~Pa}$. This sudden decrease in apparent viscosity is similar to that observed by Afonso and Maia (1999) when carrying out the rheological monitoring of

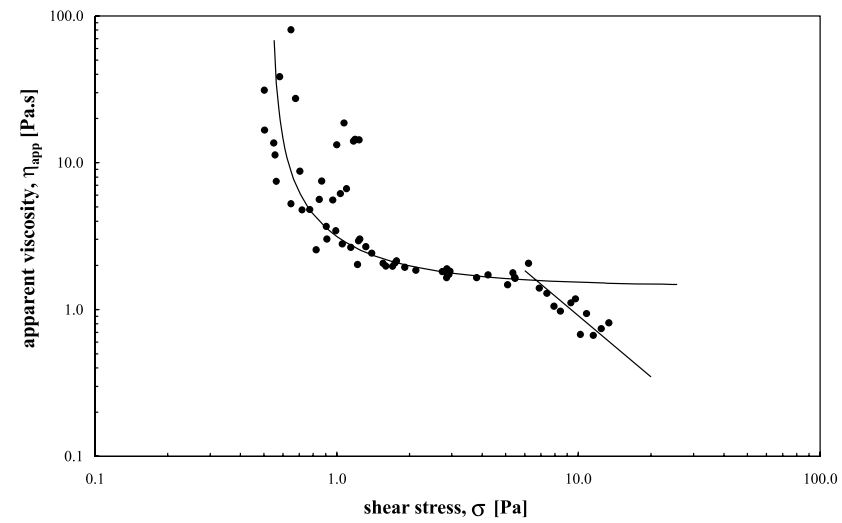

Fig. 4. Master curve at $20^{\circ} \mathrm{C}$.

structure evolution in a commercial stirred yoghurt. In that study, the authors observed similar behaviours with stirred yoghurt samples collected in a local dairy at the same stage of production (after cooling), at a shear stress of approximately 8.0 Pa. This inflection point might be due to the disruption of the primaryaggregates, breaking the portion of the casein network that was associated with exopolysaccharides produced by lactic acid bacteria, as reported by Afonso and Maia (1999). Thus, in order to better characterise the flow behaviour of stirred yoghurt two distinct behaviours, delimited by the inflection point, are considered and modelled. The rheological model that better describes the flow behaviour of stirred yoghurt can be mathematically expressed as

$\sigma=\sigma_{0}+K_{1} \dot{\gamma}$ for $\sigma<6.7 \mathrm{~Pa}$

$\sigma=K_{2} \dot{\gamma}^{n} \quad$ for $\sigma \geqslant 6.7 \mathrm{~Pa}$ 
where $\sigma_{0}$ is the yield stress $(\mathrm{Pa}), K_{1}$ and $K_{2}$ are the consistency indices $\left(\mathrm{Pa} \mathrm{s}^{n}\right)$ and $n$ is the flow behaviour index (-). So, at shear stresses lower than 6.7 Pa, the stirred yoghurt exhibits a Bingham viscoplastic behaviour with a yield stress $\left(\sigma_{0}\right)$ of approximately $0.54 \mathrm{~Pa}$ and a consistency index $\left(K_{1}\right)$ of $1.45 \mathrm{~Pa}$. At shear stresses higher than $6.7 \mathrm{~Pa}$, the stirred yoghurt exhibited a strong shear-thinning character described by a power-law model with the following parameters: $K_{2}=3.65 \mathrm{~Pa} \mathrm{~s}^{0.42}$ and $n=0.42$.

The value obtained for the flow behaviour index $(n=0.42)$, at shear stresses higher than $6.7 \mathrm{~Pa}$, emphazises the pronounced pseudoplastic character of stirred yoghurt. This value is comparable to values mentioned in the literature (ranging from 0.12 to 0.41 ), obtained with different rheological models, for example, Hershel-Bulkley (Benezech \& Maingonnat, 1992, 1993) and power-law (Rohm \& Kovac, 1995; Hassan, Frank, Schmidt, \& Shalabi, 1996; Hess, Roberts, \& Ziegler, 1997).

\subsection{Convective heat transfer coefficients}

In order to assess the experimental error associated with the determination of the thermal conductivity, a set of experiments with water was carried out, and the values thus obtained were compared to the values reported in the literature. The average experimental value obtained for the thermal conductivity of water, at $20^{\circ} \mathrm{C}$, was $0.606 \mathrm{~W} \mathrm{~m}^{-1} \mathrm{~K}^{-1}$, which is quite close to the value reported in the literature, $0.597 \mathrm{~W} \mathrm{~m}^{-1} \mathrm{~K}^{-1}$ (Çengel, 1998).

The thermal conductivity measured for the stirred yoghurt was $0.523 \mathrm{~W} \mathrm{~m}^{-1} \mathrm{~K}^{-1}$ (average value), which is comparable to the value supplied by a producer of industrial equipment for the dairy industry, 0.510 $\mathrm{W} \mathrm{m}^{-1} \mathrm{~K}^{-1}$ (APV Portugal, 1998).

The specific heat of stirred yoghurt, calculated by means of Eq. (12) considering the average water content of stirred yoghurt as $80 \%(\mathrm{w} / \mathrm{w})$, was $3.52 \mathrm{~kJ} \mathrm{~kg}^{-1} \mathrm{~K}^{-1}$.

It was assumed that within the temperature ranges of the plate heat exchanger, the thermal conductivities and the specific heats of the cooling water and the stirred yoghurt were approximately constant.

The density dependency of the stirred yoghurt on temperature was also measured, at the temperature range under study. A weak dependency on temperature was observed. The density values of the stirred yoghurt ranged from 1042 to $1071 \mathrm{~kg} \mathrm{~m}^{-3}$.

Knowledge of the convective heat transfer coefficients of the cooling water was needed in order to evaluate the yoghurt convective coefficients in the plate exchanger (there was no assurance that the existing correlations for Newtonian fluids could be applied to the particular plate heat exchanger used in the present work). For this purpose, cold and hot water were circulated through the heat exchanger and the heat transfer rate between the two liquids was calculated from the measured flowrates and temperatures.

Differences between the rates of heat transfer to the cold water and from the hot water were observed, evidencing the occurrence of some heat exchange with the surrounding air. This was more significant $(7 \%)$ when a higher number of plates was used, due to the increasing surface area in contact with the exterior, despite the insulation used in order to minimize the heat losses.

For cold water, the semi-empirical correlation obtained for the convective heat transfer coefficient was

$N u=0.218 \operatorname{Re}^{0.59} \operatorname{Pr}^{0.4}, \quad R^{2}=0.9697$

assuming that the Prandtl number exponent is $m=0.4$. These results confirmed other conclusions published in the literature for Newtonian fluids (Raju \& Bansal, 1986).

Once the correlation for the water convective coefficient was established, experiments were carried out to cool the yoghurt using cold water in the exchanger.

The experiments for the determination of pressure drop along the plate heat exchanger showed that the friction factor depended on the Reynolds number to the power -1.15 , which is close enough to the theoretical value for laminar flow $(-1.0)$ to suggest that this is indeed the flow regime present inside the plate heat exchanger.

Table 2 shows the values of the heat transfer rate in each experiment characterised by a given total number of plates and Reynolds number, as a function of the volumetric flowrates of each fluid. As in the heat transfer experiments with water only, heat losses were more significant $(8 \%)$ when increasing the total number of plates.

Table 2

Average values of the amount of heat transfered $(q)$, Reynolds numbers of the cold water $\left(R e_{\mathrm{cw}}\right)$ and stirred yoghurt $\left(R e_{\mathrm{yog}}\right)$ and total plate number of each heat transfer experiment carried out in the plate heat exchanger

\begin{tabular}{lccc}
\hline $\begin{array}{l}\text { Total plate } \\
\text { number }\end{array}$ & $R e_{\mathrm{cw}}(-)$ & $R e_{\mathrm{yog}}(-)$ & $q(\mathrm{~W})$ \\
\hline 15 & 395 & 0.51 & 2739.7 \\
15 & 366 & 0.75 & 3070.3 \\
15 & 431 & 1.71 & 4079.3 \\
13 & 422 & 0.82 & 3279.6 \\
13 & 441 & 2.09 & 4487.9 \\
13 & 497 & 3.20 & 4617.3 \\
11 & 428 & 1.25 & 2766.7 \\
11 & 565 & 2.76 & 3831.1 \\
11 & 565 & 4.85 & 4124.0 \\
7 & 784 & 3.51 & 2525.8 \\
7 & 893 & 9.43 & 3289.9 \\
7 & 856 & 11.32 & 3106.1 \\
5 & 1259 & 6.36 & 2188.7 \\
5 & 1151 & 9.19 & 2264.0 \\
5 & 1144 & 14.47 & 2600.0 \\
\hline
\end{tabular}




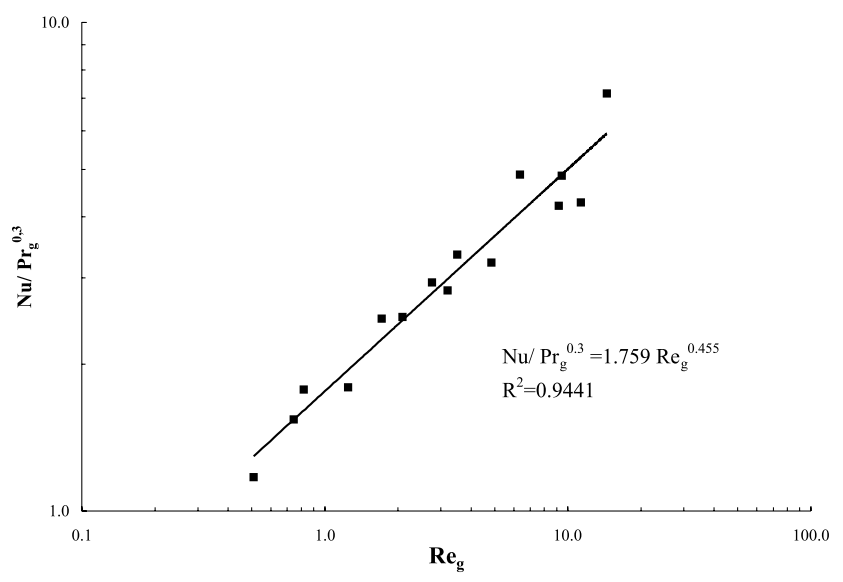

Fig. 5. Thermal correlation for the convective heat transfer coefficient of the stirred yoghurt, as a function of the Reynolds number.

Fig. 5 shows the experimental convective heat transfer coefficient of stirred yoghurt, as a function of the "generalised" Reynolds number, and the corresponding correlation is

$N u=1.759 \operatorname{Re}_{\mathrm{g}}^{0.455} \operatorname{Pr}_{\mathrm{g}}^{0.3}$

The generalised dimensionless numbers were calculated by means of Eqs. (9) and (10) where

$\eta_{\text {app }}=K \dot{\gamma}^{n-1} \quad$ if $\sigma \geqslant 67 \mathrm{~Pa}$

The apparent viscosity $\left(\eta_{\text {app }}\right)$ of stirred yoghurt assumed the power-law form presented in Eq. (17) because the shear stress during the heat transfer experiments was always higher than $6.7 \mathrm{~Pa}$ (it varied from 24 to $59 \mathrm{~Pa}$ ). In order to include the effects of temperature on the flow behaviour of stirred yoghurt, a term of the Arrhenius type was introduced in Eq. (17), yielding

$\eta_{\text {app }}=\left[K \dot{\gamma}^{n-1}\right] \mathrm{e}^{(E / R T)}$

Eq. (18) results from Eqs. (11) and (17).

Eq. (16) is not in accordance with most of the previous results obtained with other types of fluids. The Reynolds number exponent in Eq. (16), around 0.46, is similar to those reported by Edwards (1988) in plate heat exchangers operating in the laminar regime, but it is significantly higher than the exponent $1 / 3$ obtained by Rene et al. (1991). Furthermore, the values of the Nusselt number in the present work are also higher than those reported by other authors in the laminar regime (Edwards, 1988; Rene et al., 1991).

The following expression is obtained if Eq. (16) is written in terms of the Graetz number:

$N u=0.893 G z^{0.536}$

According to the Graetz solution for the the case of developing thermal laminar boundary layers inside pipes and channels with Poiseuille flows, the Nusselt number should vary with the Graetz number to the power $1 / 3$, which does not agree with Eq. (19). The latter is similar to the expression developed for the case of plug flow velocity profile (Bird, Armstrong, \& Hassager, 1987), which can occur for fluids showing a yield stress. However, the stirred yoghurt under the operating conditions prevailing in the plate heat exchanger $(\sigma \geqslant 6.7 \mathrm{~Pa})$ has a predominant pseudoplastic behaviour.

To explain these differences, it is important to note that the plate heat exchanger used here was quite short. Most of the above mentioned literature does not contain explicit information about the length of the plate, except Rene et al. (1991), who used plates of $63 \mathrm{~cm}$ length, which are almost three times longer than the plates used in the present work. Here, the high Prandtl numbers of the stirred yoghurt (between 581 and 1867) combined with the short length of the plates produced a thermal boundary layer that was far from being fully developed. It is well known that when developing boundary layers prevail, the shorter the distance from the inlet the higher will be both the average convective heat transfer coefficient and its dependency on the Reynolds number. Therefore, for similar Reynolds numbers, different values of Nusselt numbers and different correlations are to be expected for plates of different lengths, mainly when working with high Prandtl number fluids. The problem needs further attention both from the theoretical and experimental viewpoints. In particular, experimental work with plate heat exchangers with different lengths is recommended.

\section{Conclusions}

From this work with stirred yoghurt carried out under conditions similar to the ones prevailing in industrial yoghurt production, it could be concluded that this fluid exhibits a complex flow behaviour that can be described by a Bingham plastic model for shear stresses lower than 6.7 $\mathrm{Pa}$, and by a power-law model for shear stresses higher than 6.7 $\mathrm{Pa}$. Temperature effects were included in the rheological model by means of an Arrhenius type term. As regards the heat transfer behaviour of the nonNewtonian stirred yoghurt, a correlation for the convective heat transfer coefficient was obtained that reveals the effects of the thermal entry length due to the high Prandtl numbers and to the short length of the plates used in the exchanger. Such effects resulted in: (a) higher values of the convective coefficients; (b) a dependency on the Reynolds number (exponent of 0.46) that is higher than in laminar fully developed thermal boundary layers and higher than the exponent obtained by other authors for non-developed boundary layers with longer plates.

\section{Acknowledgements}

The authors would like to thank LACTOGAL, in particular, to Ms. Regina Brito and Ms. Maria José 
Ramos, from the Vila do Conde Unit for their collaboration.

\section{References}

Arshad, M., Paulsson, M., \& Dejmek, P. (1993). Rheology of buildup, breakdown, and rebodying of acid casein gels. Journal of Dairy Science, 76, 3310-3316.

Afonso, I. M., \& Maia, J. M. (1999). Rheological monitoring of structure evolution and development of stirred yoghurt. Journal of Food Engineering, 42, 183-190.

APV-Portugal. (1998). Private communication.

Barnes, H. A., Hutton, J. F., \& Walters, K. (1989). An introduction to rheology. Rheology series. Amsterdam: Elsevier.

Bassiouny, M. K., \& Martin, H. (1984a). Flow distribution and pressure drop in plate heat exchangers-I. U-type arrangement. Chemical Engineering Science, 39(4), 693-700.

Bassiouny, M. K., \& Martin, H. (1984b). Flow distribution and pressure drop in plate heat exchangers-II. Z-type arrangement. Chemical Engineering Science, 39(4), 701-704.

Benezech, T., \& Maingonnat, J. F. (1992). Flow properties of stirred yogurt: modelling and influence of cooling conditions. In P. Moldenaers \& R. Keunings (Eds.), Theoretical and applied rheology proceedings XIth international congress on rheology, Brussels, Belgium. London: Elsevier.

Benezech, T., \& Maingonnat, J. F. (1993). Flow properties of stirred yoghurt: structural parameter approach in describing time-dependency. Journal of Texture Studies, 24, 455-473.

Benezech, T., \& Maingonnat, J. F. (1994). Characterization of the rheological properties of yoghurt-a review. Journal of Food Engineering, 21, 447-472.

Bird, R. B., Armstrong, R. C., \& Hassager, O. (1987). Dynamics of polymeric liquids, Vol. 1 (second ed.). New York: John Wiley \& Sons Inc.

Bouzar, F., Cerning, J., \& Desmazeaud, M. (1997). Exopolysaccharide production and texture-promoting abilities of mixed-strain starter sultures in yogurt production. Journal of Dairy Science, 80, 2310 2317.

Çengel, Y. A. (1998). Heat transfer: a practical approach. International edition. Boston: WCB/McGraw-Hill Companies Inc.

Corrieu, G., Noël, Y., \& Maingonnat, J. F. (1985). Liquides alimentaires complexes caractérisation rhéologique et traitement thermique. Revue Générale de Thermique, 279, 229-240.

Delplace, F. (1995). Identification des échangeurs de chaleur à plaques: application à l'étude de l'encrassement par produits laitiers. Université Henri Poincaré, Nancy.

Edwards, M. F. (1988). Heat transfer in plate heat exchangers at low Reynolds numbers. In S. Kakaç (Ed.), Low Reynolds number forced convection in channels and bundles applied to heat exchangers (pp. 23-37). Turkey: NATO Advanced Study Institute.

Hallström, B., Skjöldebrand, C., \& Trägårdh, C. (1988). Heat Transfer and Food Products. Essex: Elsevier Applied Science Publishers Ltd.

Hassan, A. N., Frank, J. F., Schmidt, K. A., \& Shalabi, S. I. (1996). Rheological properties of yogurt made with encapsulated nonropy lactic cultures. Journal of Dairy Science, 79, 2091-2097.

Heggs, P. J., Sandham, P., Hallam, R. A., \& Walton, C. (1997). Local tranfer coefficients in corrugated plate heat exchanger channels. Transactions of the Institution of Chemical Engineers, 75, Part A, 641-645.
Hes, L., Araújo, M., \& Djulay, V. (1996). Effect of mutual bonding of textile layers on thermal insulation and thermal-contact properties of fabric assemblies. Textile Research Journal, 60, 245-250.

Hess, S. J., Roberts, R. F., \& Ziegler, G. R. (1997). Rheological properties of nonfat yogurt stabilized using Lactobacillus delbrueckii sp. bulgaricus producing exopolysaccharide or using commercial stabilizer systems. Journal of Dairy Science, 80, 252-263.

Kaláb, M., Wojtas, P. A., \& Told, B. E. P. (1983). Development of microstructure in set-style nonfat yoghurt-a review. Food Microstructure, 2, 51-66.

Kho, T., \& Müller-Steinhagen, H. (1999). An experimental and numerical investigation of heat transfer fouling and fluid flow in flat plate heat exchangers. Transactions of the Institution of Chemical Engineers, part A, 77, 124-130.

Leuliet, J.-C., Maingonnat, J.-F., \& Lalande, M. (1987). Étude de la Perte de Charge dans des Échangeurs de Chaleur à Plaques Traitant des Produits Non-Newtoniens. Revue Générale de Thermique Fr., 308-309, 445-450.

Leuliet, J.-C., Maingonnat, J.-F., \& Lalande, M. (1990). Écoulements et Transferts dans les Échangeurs à Plaques Traitant des Produits Visqueux Newtoniens et Pseudoplastiques. The Canadian Journal of Chemical Engineering, 68, 220-229.

Lucey, J. A., Teo, C. T., Munro, P. A., \& Singh, H. (1997). Rheological properties at small (dynamic) and large (yield) deformations of acid gels made from heated milk. Journal of Dairy Research, 64, 591-600.

Muley, A., Manglik, R. M., \& Metwally, H. M. (1999). Enhanced heat transfer characteristics of viscous liquid flows in a chevron plate heat exchanger. Journal of Heat Transfer, 121, 1011-1017.

Nielsen, L. E. (1977). Polymer rheology. New York: Marcel Dekker Inc.

Parnell-Clunies, E., Kakuda, Y., deMan, J. M., \& Cazzola, F. (1988). Gelation of yogurt as affected by heat treatment of milk. Journal of Dairy Science, 71, 582-588.

Raju, K. S. N., \& Bansal, J. C. (1986). Design of plate heat exchangers. In J. W. Palen (Ed.), Heat exchanger sourcebook (pp. 563-582). Berlin: Springer-Verlag.

Rao, M. A. (1986). Rheological properties of fluid food. In M. A. Rao \& S. S. H. Rizvi (Eds.), Engineering properties of food (pp. 1-47). Basel: Marcel-Dekker, Inc.

Rene, F., \& Lalande, M. (1987). Échangeur de Chaleur à Plaques et Joints. Résolution Numérique des Équations D'Échange Thermique entre les Différents Canaux. Revue Générale Thermique Fr., $311,577-583$.

Rene, F., Leuliet, J. C., \& Lalande, M. (1991). Heat transfer to Newtonian and non-Newtonian food fluids in plate heat exchangers: experimental and numerical approaches. Transactions of the Institution of Chemical Engineers, 69, Part C, 115-126.

Rohm, H., \& Kovac, A. (1994). Effects of starter cultures on linear viscoelastic and physical properties of yogurt gels. Journal of Texture Studies, 25, 311-329.

Rohm, H., \& Kovac, A. (1995). Effects of starter cultures on small deformation rheology of stirred yoghurt. Lebensmittel-Wissenschaft und-Technologie-Food Science and Technology, 28, 319-322.

Rönnegård, E., \& Dejmek, P. (1993). Development and breakdown of structure in yoghurt studied by oscillatory rheological measurements. Le Lait, 73, 371-379.

Sweat, V. E. (1986). Thermal properties of foods. In M. A. Rao \& S. S. H. Rizvi (Eds.), Engineering properties of food (pp. 49-87). Basel: Marcel Dekker, Inc.

Tamime, A. Y., \& Robinson, R. K. (1988). Fermented milks and their future trends. Part II. Technological aspects (review). Journal of Dairy Research, 55, 281-307. 